\title{
NEW ARCHAEOLOGICAL RESEARCHES AT THE ROMAN FORT FROM BĂNEASA (TELEORMAN COUNTY)
}

EUGEN S. TEODOR

\section{NOI CERCETĂRI ARHEOLOGICE ÎN CASTRUL DE LA BĂNEASA (JUD. TELEORMAN)}

În cadrul proiectului de cercetare Limes Transalutanus s-au realizat evaluări ale stării de conservare pentru siturile studiate. Castrul mare de la Băneasa - care este cea mai mare fortificație romană de pe această frontieră - nu a ieșit prea bine din acea analiză, rezultând că partea centrală a laturii de vest este deja pierdută în râpa dinspre Călmățui, iar colțurile adiacente sunt în pericol iminent. Deși în cadrul proiectului nu erau prevăzute săpături arheologice, cu excepția unor scurte sondaje mecanice pe „troian”, aceste constatări m-au determinat să fac o săpătură scurtă, informativă, la colțul de sud-vest al castrului, cel care părea cel mai afectat de eroziune.

Săpătura de diagnostic a intersectat atât săpătura lui Gheorghe Cantacuzino (din 1943), cât și o săpătură mai nouă, cu autor necunoscut. Acestea au afectat aproape o treime din suprafața deschisă $(11 \mathrm{mp})$, restul servind concluziilor care sunt detaliate în raport.

Săpătura a demonstrat că diagnosticul fusese corect. Nu doar că valul de apărare este complet pierdut, dar chiar și „nivelul de călcare antic”, pe care se construise palisada, a fost afectat de combinația dintre arăturile sistematice și înclinația naturală a platoului. Din fosta palisadă s-a mai găsit doar o groapă (parțială) de stâlp, arsă până la bază.

Față de situația dramatică a curtinei, cea constatată imediat la interior este mult mai bună. Aici au putut fi distinse, sub arătură, două niveluri distincte din epoca romană. Cel vechi a adăpostit o baracă, și ea arsă, deși mult mai puțin sever decât palisada, nivel datat cu monedă de la începutul veacului al III-lea. Nivelul mai recent sugerează, prin analiza de inventar, că arealul studiat își schimbă utilitatea, devenind zonă industrială (producție ceramică și de fier reciclat).

Analiza de inventar pentru nivelurile romane au produs câteva surprize notabile, între care cvasiabsența materialului tegular sau a celui metalic, cât și prepoderența relativă a ceramicii considerate, până recent, a aparține culturii Chilia-Militari.

$\mathrm{O}$ altă surpriză a fost existența unui nivel preistoric consistent (probabil din perioada timpurie a epocii

fierului), atât ca depunere antropică (de peste $0,5 \mathrm{~m}$ ), cât și ca pondere a ceramicii recoltate (spre $40 \%$ ).

Având în vedere rezultatele interesante din zona de interior a castrului, s-a hotărât extinderea cercetării în alte zone ale castrului mare, în vederea unui diagnostic de ansamblu mai temeinic, alături de extinderea cercetării geofizice, urmărind a pregăti situl pentru un proiect de cercetare sistematică, pe termen nedefinit. Decizia are legătură şi cu includerea castrului pe Lista Tentativă UNESCO, aflată în lucru la Comisia de Limes, cât şi cu perspectiva nevoii unui viitor proiect de exploatare turistică şi muzeală, care să beneficieze de necesarul suport ştiinţific.

CUVINTE CHEIE: Limes Transalutanus, castru, magnetometrie, topografie, săpătură test, ceramică Chilia-Militari.

KEYWORD: Limes Transalutanus, Roman fort, magnetometry, field survey, test digging, Chilia-Militari pottery.

\section{APPROACHING A FORT}

This is the largest measurable fort of the so-called Limes Transalutanus, a new frontier line built at the threshold of the second and third century ${ }^{1}$, connecting the Danube, immediately downstream the Olt River's mouth, the Bran Pass, in Southern Carpathians, and the bent of the Upper Olt, near the fort Comalău, summing about $320 \mathrm{~km}^{2}$. Possibly larger forts on this frontier could have

\footnotetext{
${ }^{1}$ Petolescu 2010, 185-186, is resuming the unfinished debate about the early stage of this construction. See also Teodor 2015, 203-204 with note 66 .

2 Tocilescu 1900, 123, gave the "standard" distance of $235 \mathrm{~km}$ for the length of this limes.
} 
had been Flămânda and Purcăreni; the former was destroyed by "carefully" planners in 1970s, which used the monument for making a dam against Danube's floods ${ }^{3}$. The later was swept away by the rivers Doamnei and Târgului, at their confluence, long time ago ${ }^{4}$. It have been preserved in modern era only one side, the western, having on the agger $126 \mathrm{~m}$, but all the others are damaged by the stream; the longest is the southern one, measuring $100 \mathrm{~m}$ on the embankment, but $150 \mathrm{~m}$ on the ditch, its other side being thus at least $138 \mathrm{~m}$ on the stone curtain. For comparison, Băneasa fort is known as having $126 \times 130 \mathrm{~m}$, as rendered by the only archaeologist digging there so far ${ }^{5}$, but a bit greater, as we shall see.

In the past two years I have led a research project known, in short, as Limes Transalutanus ${ }^{6}$, acting between Danube and Argeș River (157 km long). The project is not dedicated especially to forts, being committed in all the items making a limes, as the border embankment, the road, the watchtowers, the civilian settlements, the main effort being driven to a detailed topographical assessment. In the same time, assessing the diagnostic of the conservation status was part of our action. This way the large fort from Băneasa came into our attention in July 2015, when snapshots taken from an airplane showed a precarious situation at the western side; is was simply missing ${ }^{7}$.

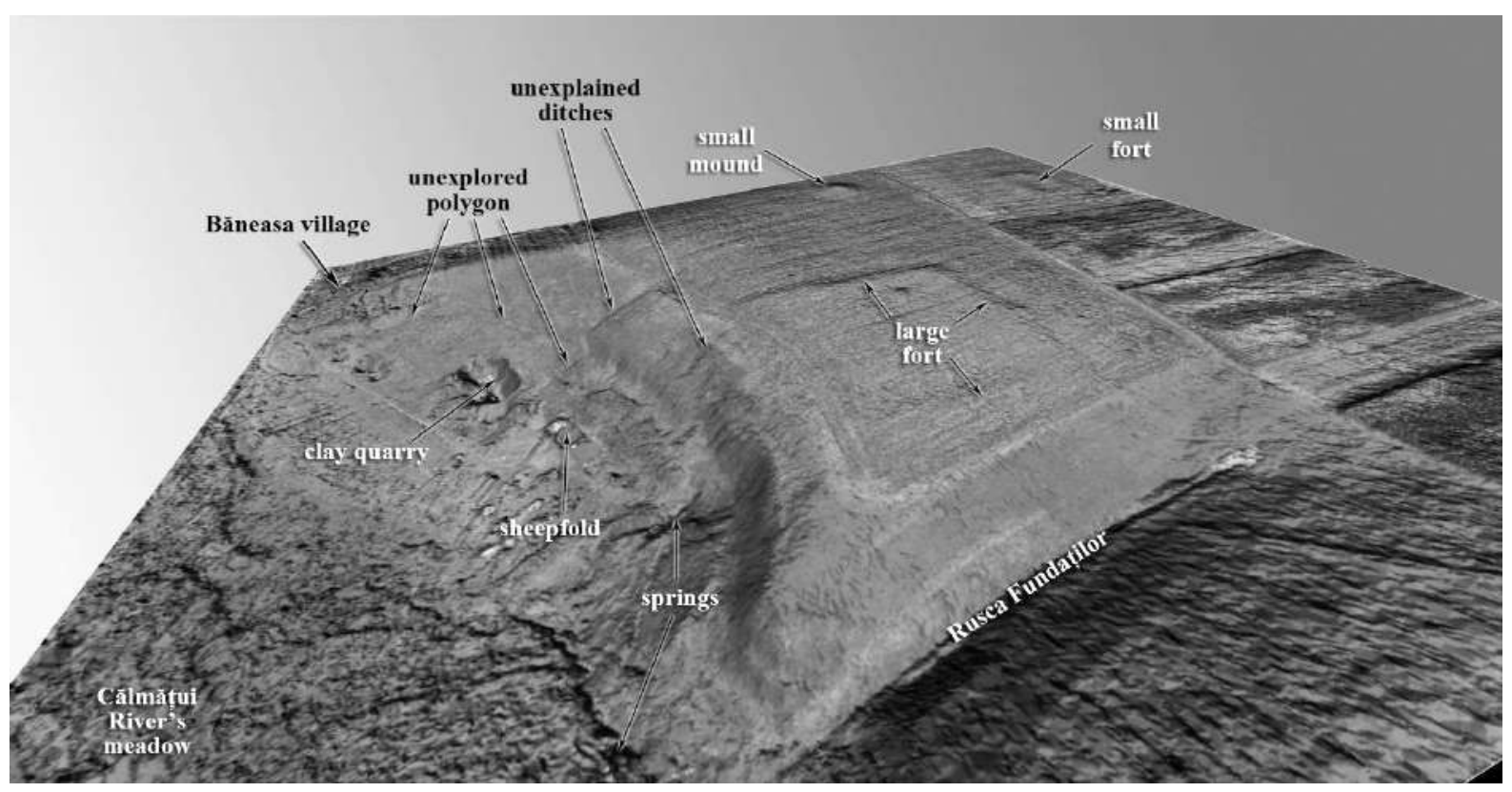

FIGURE 1: Băneasa. Virtual reality made of high definition orthophotos $(0.1 \mathrm{~m})$ and terrain model $(0.2 \mathrm{~m})$. View from south-west.

In the summer 2016 we made some steps forward in order to understand better the state of conservation. First of all, we made a new drone mission, centred on the large fort, in ideal conditions, with a field completely clean (FIG. 1). Secondly, have been made some magnetometry for areas considered the main clues, respectively a rectangle of $200 \times 40 \mathrm{~m}$, aligned to the edge of the terrace, to figure out the status of the western side of the fort; later, in autumn, has been covered another

\footnotetext{
${ }^{3}$ Bogdan-Cătăniciu 1997, 42. The original size is mentioned both by Polonic's sketch (Tocilescu 1900, 122, fig. 65) and Planul Director de Tragere (military map) no. 3636, from 1945, being around 7 hectares, far too much for a fortification of Limes Transalutanus, but matching the usual sizes of the vexillations' camps from the Trajan's war (for instance Jigoru Mare has the same dimension). After this brutal intervention, which swept up the layers of the fort, the archaeological investigation cannot be useful anymore, as Bogdan-Cătăniciu's attempt has proved. We cannot know how much of this surface was reused in the third century.

${ }^{4}$ Tocilescu 1900, 129, fig. 72.

${ }^{5}$ Cantacuzino 1945, 452 with fig. 3 and 454.

${ }^{6}$ See yet the full name and the partnership on www.limes-transalutanus.ro.

${ }^{7}$ Teodor 2016a, 103, fig. 4.
} 
surface, of $80 \times 40 \mathrm{~m}$, at the north-eastern corner ${ }^{8}$. Giving the fact that our works are oriented by a GPS from GNSS class, with virtual no error ${ }^{9}$, we are now able to change the general figures of the fort, at $139 \times 139 \mathrm{~m}$ (FIG. 2).

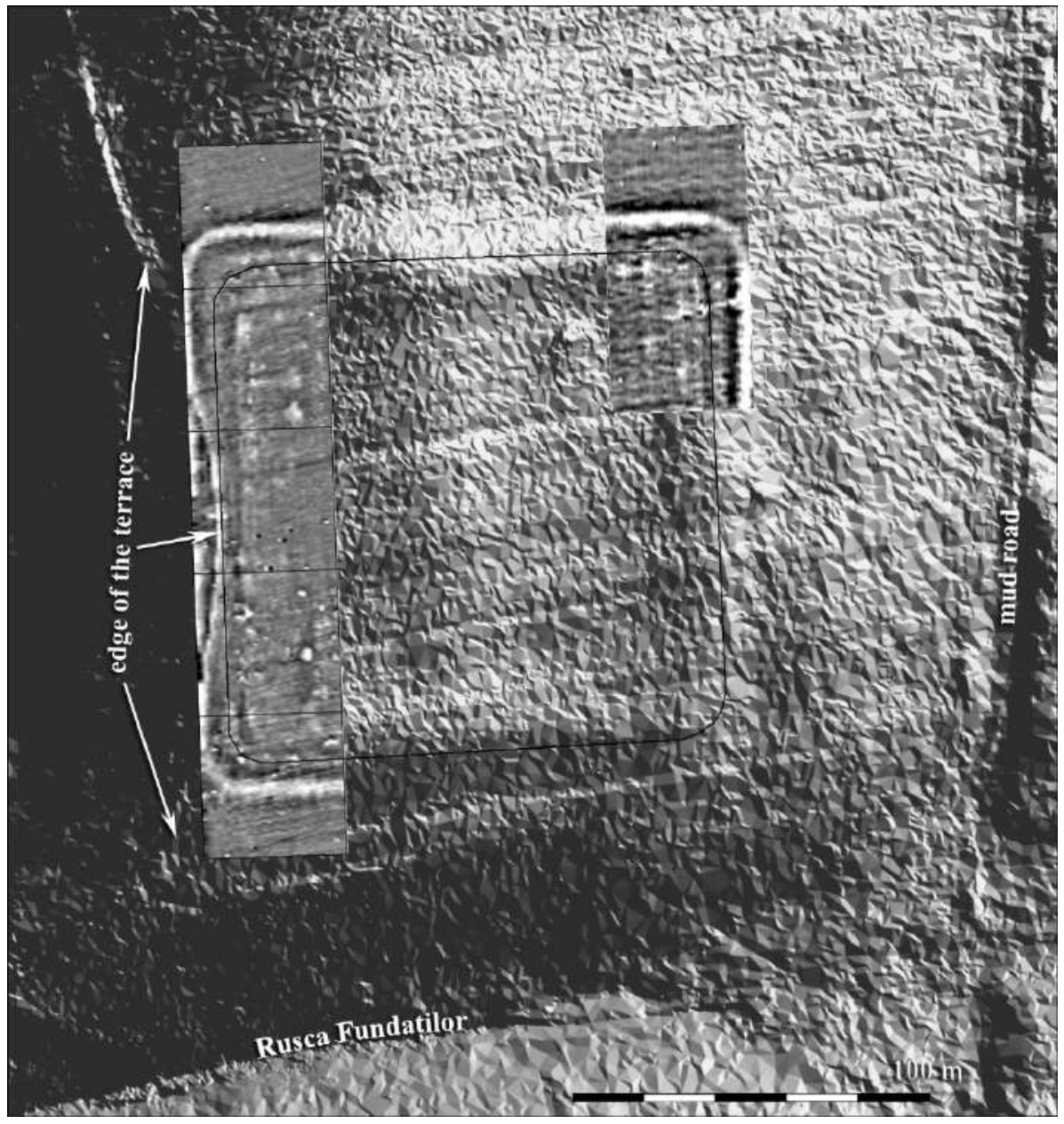

FIGURE 2: The large fort from Băneasa viewed as terrain model overlapped by magnetometry.

The magnetometric work, although far from complete, deserves some commentaries. First of all, the image from the Figure 2 is a negative depiction, in which the most magnetic soil is whitish. What we see as being white is mainly the ditch, very likely filled with burned matter. We can see one ditch running around the fort, but we also remember that Tocilescu has suggested the existence of two ditches along the northern and eastern sides, a fact making sense, as the western and southern sides are naturally protected by steep slopes ${ }^{10}$. The fact that magnetometry did not show the second ditch doesn't mean it is not there, because if it was not filled with burned matter there is nothing much to see. The existence of a second ditch north and east of the fort is also suggested by the terrain model, showing a hollow outside of the white line of the (magnetometric) ditch.

Half of the ditch from the western side is already beyond the edge of the terrace. From the embankment of the palisade one can see only parts near the rounded corner. In the inner part of the fort, a single continuous line is visible, marking the external wall of the buildings (barracks).

The analysis performed on the terrain model (resolution $0.2 \mathrm{~m}$ ) showed great discrepancies of conservation between the north-eastern corner (best preserved) and the opposite, south-western. If in the first case the embankment of the palisade (agger) is clearly visible in the field, in the second case it cannot be detected, not even on a detailed terrain model (FIG. 3). The only thing to help us

\footnotetext{
8 All geophysical works were made by Dan Ştefan, partner in the project.

9 Stonex S7-G, with expected errors of $1 \mathrm{~cm}$ on X, Y and $2 \mathrm{~cm}$ on Z.

${ }^{10}$ Tocilescu 1900, 131, fig. 74.
} 
understand the locations along the topographic section is the magnetometry (included at the FIG. 3). The reason for such a different picture is the erosion, which is favoured by two facts: first of all, a general tilt of the field, from north-east to south-west, loosing $6.6 \mathrm{~m}$ in height in $280 \mathrm{~m} \mathrm{long}$, or $1.35^{\circ}$, progressively increasing to the edge of the terrace (where is $>2^{\circ}$ ); secondly, the effect of the systematic ploughing, which accelerates the erosion, driving the minced soil downslope.

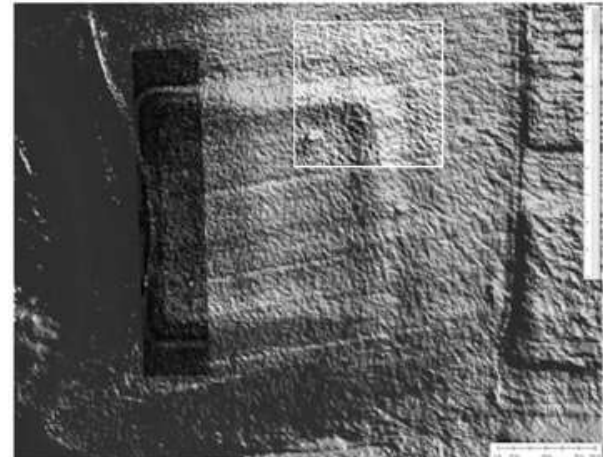

From Pos: $497126.314,270782.662$

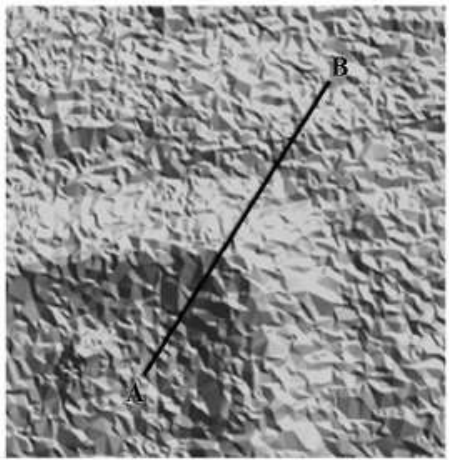

To Pos: $497086.391,270718.911$
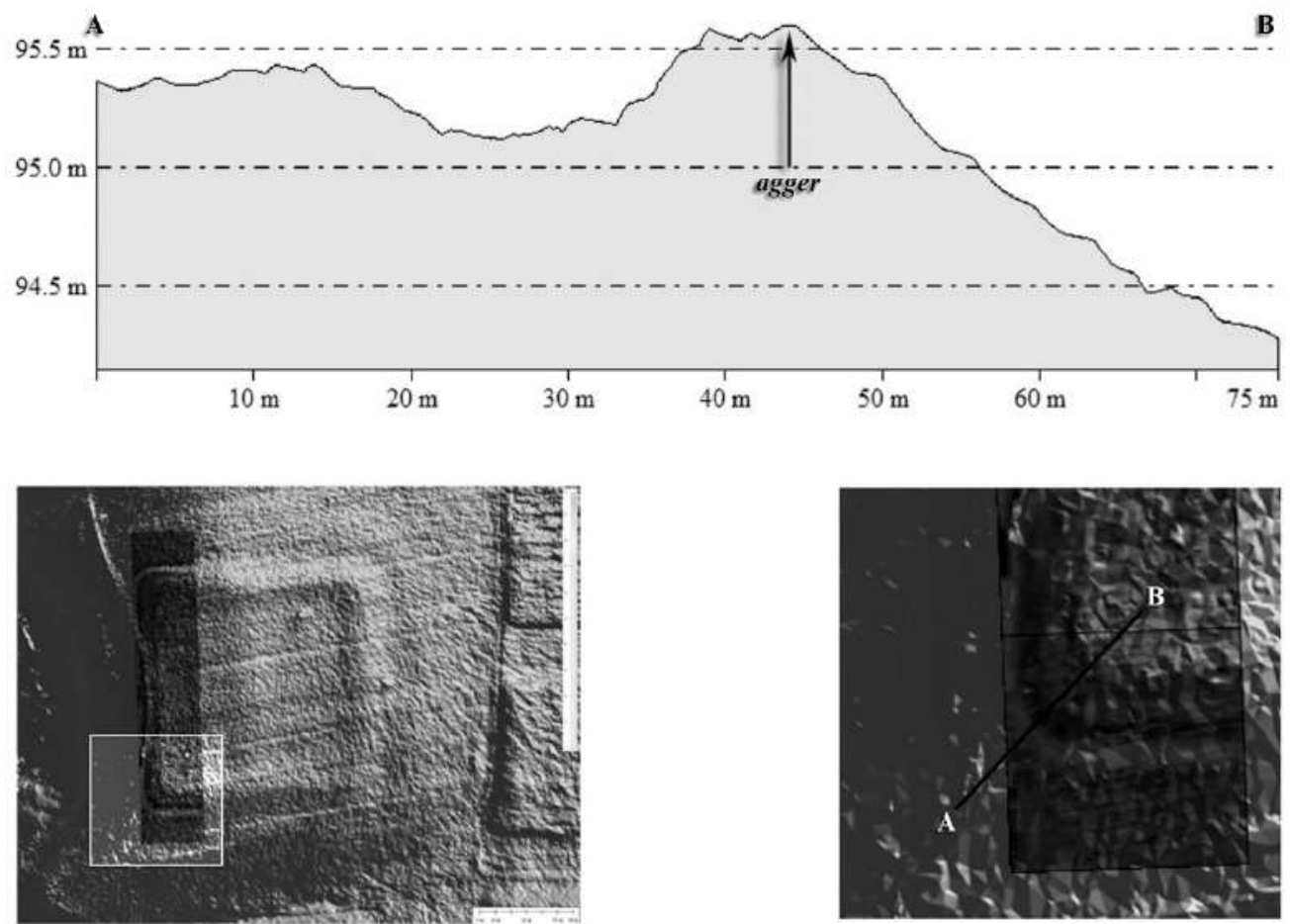

From Pos: 496961.184, 270588.298

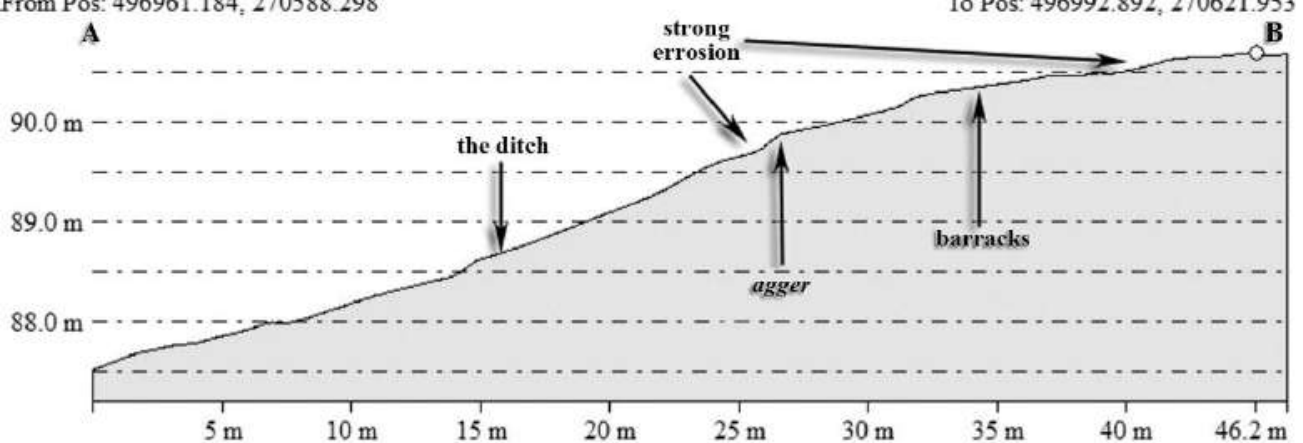

FIGURE 3: Topographical sections on high resolution terrain model overlapped by magnetometry, comparing the conservation status of the corners northeast and southwest. 
Another issue which needs a discussion is the middle embankment, dividing the area in two relatively equal parts. The middle wall appears both on the plans published by Tocilescu and Cantacuzino, and in both cases it is making unequal parts, the left one being smaller ${ }^{11}$. On the model presented at the FIG. 2 the middle wall is also visible, although stretched by ploughing, laying - with its top $-63 \mathrm{~m}$ apart from the western wall, and $76 \mathrm{~m}$ afar from the eastern wall. The profile of the median wall $-0.3 \mathrm{~m}$ in height but stretched $40 \mathrm{~m}$ ! - is symmetrical, giving no hint about his exact function; we have to expect then geophysics to tell more. A thing is still clear from the aerial picture: it is different of the large curtain walls, being less burned (if any).

Far more important that the errors in measurement are the gates suggested by the plan published by Tocilescu. An opening in the eastern embankment, $6 \mathrm{~m}$ wide, is located at $89 \mathrm{~m}$ from the north-eastern corner, and $54 \mathrm{~m}$ from the south-eastern corner. Other two openings are located roughly centred on both northern and southern sides, just near the "median" wall. No gate is depicted on the western side, but the steep slope from that part is a good reason. The state of conservation was much better when Tocilescu made its observations, in the last decade of the $19^{\text {th }}$ century: the embankment from the western side is rendered as having more than one meter in height, at the edge of the terrace! Only half a century later, when Cantacuzino performed his diggings, the embankment was already lost, as we shall see further.

To conclude this short review of some old data, Tocilescu has suggested that porta praetoria has been oriented southward, which is a bit odd, the enemy being located - "by the book" - eastward. If the south was yet more important, then we have to take note of the long and wide ravine named "Rusca Fundaţilor" (see again FIG. 2), which can support a road descending the high terrace in the foodplain of the Călmăţui River. This road should drive to the Olt River, where the former border of the empire lied in most of the second century. The most likely target of this road was not Slăveni (40 $\mathrm{km}$ ), but the area near the mouth of the Olt River, in front of the Roman forts from Islaz, from the opposite bank of the river. The distance from Băneasa to the bank of the "Small Olt" (named Sâi) is $18 \mathrm{~km}$, a standard one for one marching day. The missing link is to be found probably in the villages Olteanca or Segarcea.

A second and obvious conclusion is that this is an endangered site, which lost $25 \mathrm{~m}$ in one century, and the process is far from over, due to the present day ploughing, deeper than ever ${ }^{12}$.

\section{THE TEST DIGGING}

The above conclusions became obvious to me in early August 2016. Although a digging was not planned and a shortage of founds was predictable ${ }^{13}$, I have decided to make a test digging in the most endangered area, at the south-western corner of the fort. It happened between 5 and 15 September 2016.

Looking to the plan published by Cantacuzino I found a $20 \times 1.5 \mathrm{~m}$ trench on the same area, oriented more or less perpendicular on the rounded corner ${ }^{14}$. In order to avoid digging too much in the old trench, I made a plan containing four surfaces of $3 \times 3 \mathrm{~m}$, closing a square plan with $7 \mathrm{~m}$ on side, oriented to the cardinal directions, and named accordingly: North, West, South, and East.

The Surface North (noted currently S.N) was firstly done, the old trench being immediately located (FIG. 4). Odd enough, parallel with the trench Cantacuzino was discovered another, with the same orientation, about one meter wide (but shrinking to the base). In order to make things clearer, I opened the Section West (S.W) and a new one, not planned, named S.1, in the opposite direction, both measuring $3 \times 2 \mathrm{~m}$. It came out that the "one meter trench" is also an archaeological digging, not

\footnotetext{
11 Tocilescu 1900, 131, fig. 74; Cantacuzino 1945, 452, fig. 3. Due to the technical means available (for archaeologists!) in those times, there are inconsistences between the figures inscribed and the measured lengths. This is not really relevant today.

${ }^{12}$ For now I got a "truce" with the administrator of the land, which is planning to grow clover, a plantation which needs only one (superficial) plough for about the next six years. Being a quasi-permanent plantation, it could help diminishing the erosion near the edge of the terrace.

${ }^{13}$ I asked and received a small - but useful - help from the History National Museum Budget.

${ }^{14}$ Cantacuzino 1945, 451-452 with the fig. 3.
} 
known (reported). Not only that the stratigraphy has pinpointed the idea, but also the granularity of the burned adobe - a matter with a high occurrence in the area. If the burned adobe from the old Cantacuzino trench had, in average, the size of an orange, in the so-called "one meter trench" the same matter did not exceed the size of a nut. Obviously, we are dealing with a relatively recent digging, with the upper layer (containing burned adobe) crumbled by the plough. This is another proof of the archaeological site's decay.

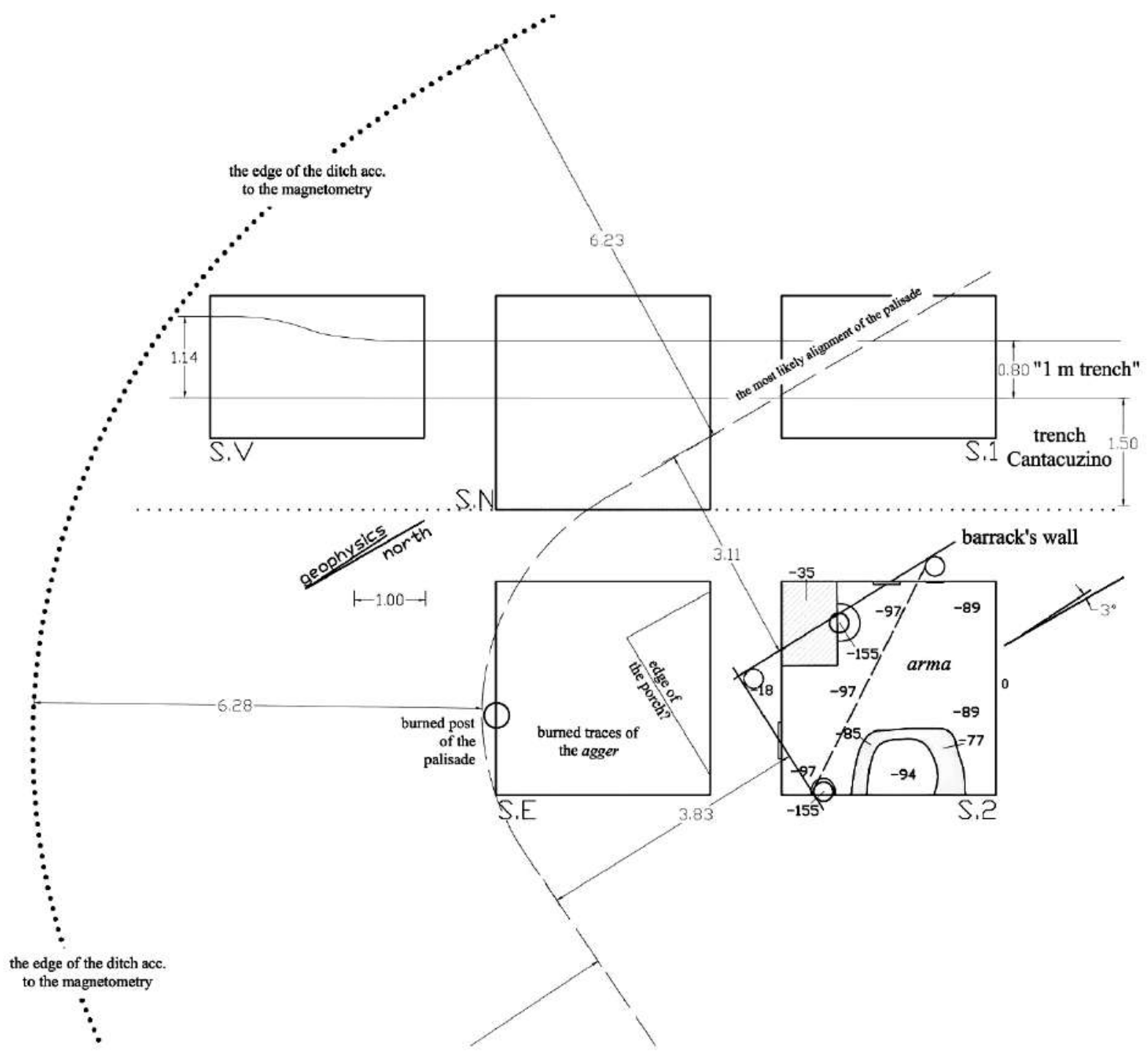

FIGURE 4: Băneasa, the large fort, plan of the test-diggings from September, 2016.

Those three surfaces from the north-western side of the test-digging area (W, N, 1) did not bring very much of new information, other than the stratigraphy from the north-western sections, but the comparison with Cantacuzino's research is instructive (FIG. 5). Although the correspondence of the two sets of depiction cannot be yet established (the north-eastern limit of the older digging is not known), some things are yet clear. First of all, the curvature of the field, as depicted by Cantacuzino, is lost, as another result of the erosion; the slope is now almost flat. It was not always flat, as shown by the shape of the natural layer, as seen in the drawing from the bottom. Secondly, the height of the layer containing lots of burned adobe is shrinking, at less than half compared with the situation recorded 70 years ago.

The most astonishing difference between the first and the later depiction of the same spot of the site is the thick layer containing artefacts belonging to the Prehistory, previously not reported. 
That layer is $0.5 \mathrm{~m}$ thick and, of course, delivered lots of handmade pottery, difficult to confuse with Roman Age artefacts.

Gh. Cantacuzino, Băneasa 1943, trench D, north-western profile

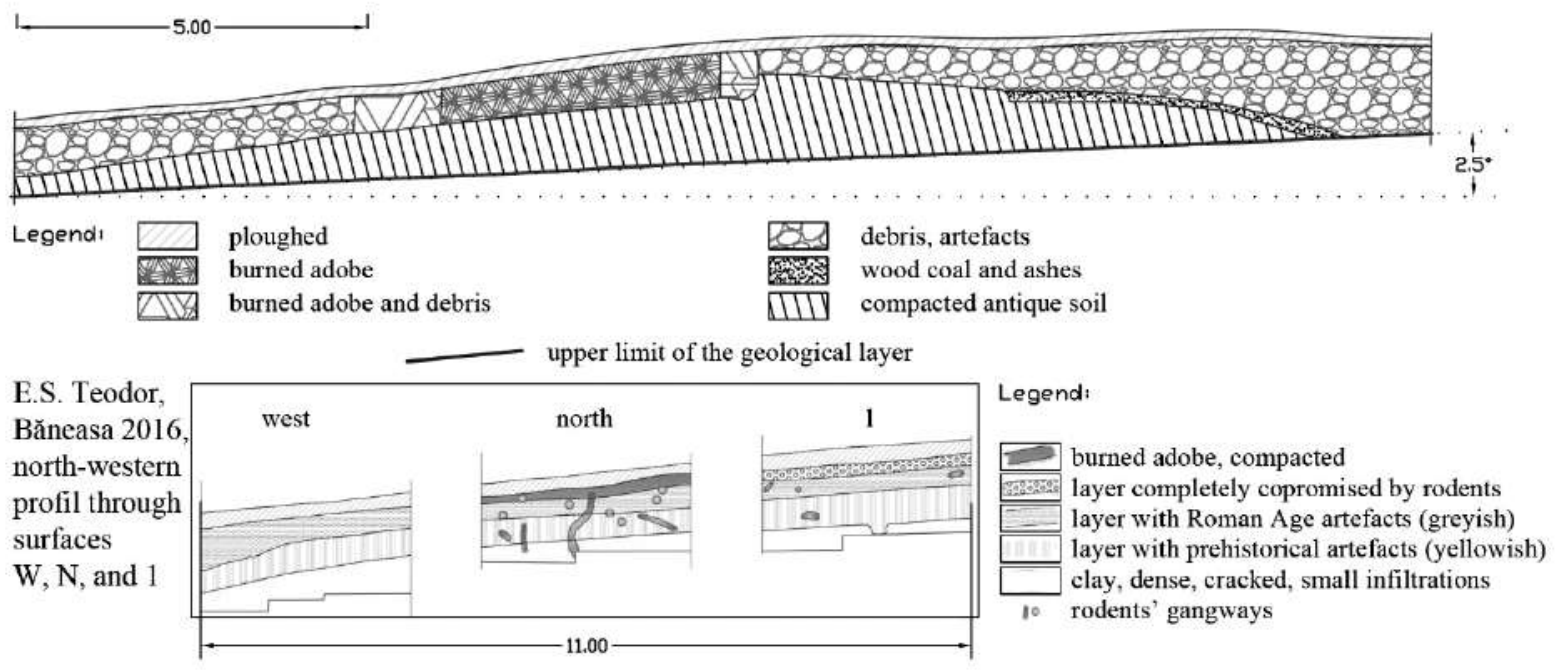

FIGURE 5: Compared stratigraphic sections at the south-western corner of the fort, diggings from 1943 and 2016.

The remaining other two surfaces under research, East and 2, both large of $3 \times 3 \mathrm{~m}$, were the only left to make a proper digging. Surface East is yet located in an area extremely affected by the erosion. No part of it conserved the foot level of the Roman Age, originally located at least one meter above; as a consequence, almost all artefacts were found in secondary position. Near the north-eastern side of the surface, and just beneath the ploughed layer, has been revealed a strongly burned level, making a $90^{\circ}$ turn, shadowing the corner of the neighboured barrack. That's why it could be the porch of the barrack, if not just crumbled ruins of it.

FIGURE 6: Stratigraphic section in Surface E, profile of southwest. Large pit post of the palisade.

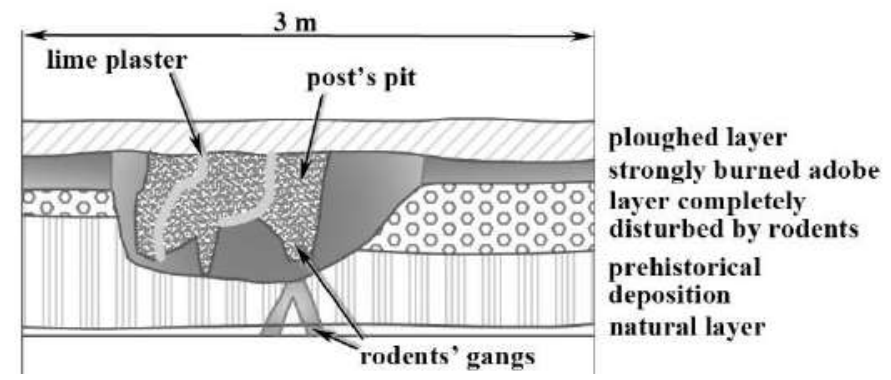

The middle of the S.E was covered with other burned adobe lumps, probably rolled by the plough. The only thing still in its original position is a large post, incredible burned, most likely being part of the palisade structure (FIG. 6), located on the south-western section. The insertion pit is as large as $0.94 \mathrm{~m}$, but the diameter of the post seems no greater than $0.36 \mathrm{~m}$, fact suggested by the thick layer of lime plaster which originally enveloped the log. The pit was largely hollowed by rodents, extremely active in the area, but mainly in that pit, filled with burned adobe of small sizes, easier to be dug. The fire was extremely strong, descending into the pit down to the bottom, today $0.52 \mathrm{~m}$ in deep, but at least $1.50 \mathrm{~m}$ in antiquity. Around the pit the earth turned red for at least $0.2 \mathrm{~m}$, an unprecedented fact in my career in archaeology.

The last surface investigated, named S.2, gave from far the most relevant data (see again FIG. 4, next FIG. 7). Closely after clearing the ploughed layer, came out a layer containing small fragments 
of charcoal, ashes and pottery sherds, especially in the western half. There have been located three postholes: on the south-eastern section, near the western corner (cut in half, as in the plan from the FIG. 4) and beyond the north-western section (with traces on the upper stratigraphy). Near two of them the stratigraphy showed adobe walls collapsed to the northwest, indicating a building. The outer faces (the bottom in stratigraphy) have had clear marks of lime plaster. Both holes available to dig proved deep, ending $1.45 \mathrm{~m}$ below the present day surface, and $0.75 \mathrm{~m}$ below the construction level. The holes have different diameters (from 0.35 to $0.5 \mathrm{~m}$ ), but probably the posts were even, around $0.3 \mathrm{~m}$. In both cases the post has been removed (for reuse?), from the bottom of the holes being recovered pottery sherds, burned adobe and charcoal.

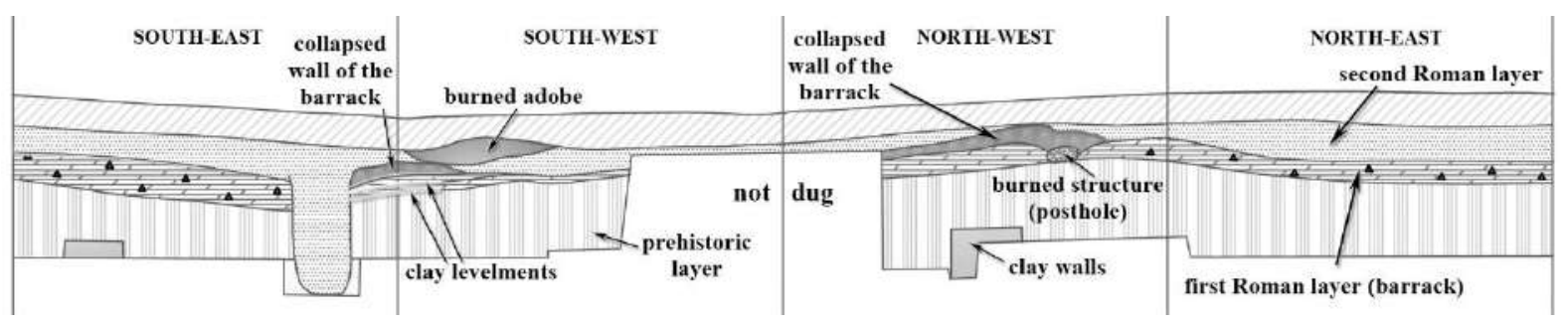

FIGURE 7: Stratigraphic sections in the Surface 2, inside the barrack.

The floor of the barrack has been fitted with a thin layer of clay, conserved here and there, being repaired once. The floor is not flat, as expected, but tilts, with differences of level up to $0.25 \mathrm{~m}$. The reason is plain: the building was not set on solid ground, but on a thick deposit of the Prehistory, measuring as much as $0.6 \mathrm{~m}$.

The filling layer of the barrack has an average thickness around $0.25 \mathrm{~m}$. Its composition (mainly charcoal and ashes) suggests a roof made of light materials, like reed (abundant in the meadow). No tiles have been recovered from this layer. The logs from the roof structure seem removed, no part of large woods being preserved. Recovery of the posts of the walls, as well as the absence of the roof structure, suggest that the site was not abandoned after the fire, the rubbles being removed. Anyway, no other construction was been made here.

The layer which tops the barrack's remains was considered, in the digging time, as an "abandon" layer. Too disturbed by rodents to be really analysed, it seemed to be, at the time, homogenous, with artefacts probably rolled on the slope. The archaeological inventory analysis, performed post digging, showed a completely different thing: from this layer are coming potsherds brand new, when not obviously refuses. In the same place was found a piece of molten iron, laminated, weighing $30 \mathrm{~g}$, with one side covered in sand, from the furnace's wall. These hints offered by the artefacts' analysis have to be added to previously mentioned observations, as the removal of the barrack's posts.

We can recall now the so-called median embankment of the fort. The working hypothesis is that after the fire which has struck the entire curtain of the large fort, it was rebuilt, but the western side was withdrawn 63 meters. Obviously, the remaining garrison was much smaller. The part left outside the new curtain became an industrial area, as pottery making or iron melting (most likely recycling).

The magnetometry was essential for understanding the layout of the barrack, giving the small size of the digging inside it (about $8 \mathrm{~m}^{2}$ ). The first guess was to connect the two fragments of the barrack's walls (as shown by the dashed line at the FIG. 4), but the magnetometry was suggesting that the barrack is aligned almost north, driving to a new design, as hypothetical as it is. The digging was probably located at the very end of the barrack, made in arma, the front room, in order to have the exit directly on the battlements; the distance from the outer wall of the barrack to the palisade is between 3 and $4 \mathrm{~m}$. Of course, in such a tiny space there was no room for a tower, not necessary, in fact, because the corner of the fort is adjacent with steep slopes, averaging $20^{\circ}$ heading Călmățui (with a maximum of $45^{\circ}$ ) and $11^{\circ}$ heading Rusca Fundaților (with a maximum of $23^{\circ}$ ). 
Knowing the previous research conducted by Gheorghe Cantacuzino, I was not expecting surprises like the Prehistory, a cultural layer developed on a constant height of 0,5-0,6 $\mathrm{m}$, a living at least as consistent as the Roman one. In the same surface where the barrack was studied, S.2, I found also some clay fittings at the bottom of my digging. Near the south-eastern section it was a closed space, with roughly round plan, covering about $0.8 \mathrm{~m}^{2}$, made of clean, light yellowish clay, with paraments widths of $0.2-0.35 \mathrm{~m}$, found on a maximum height of $0.17 \mathrm{~m}$. Although its plan is looking like a hearth, I found no trace of fire, the purpose being rather connected with keeping safe something (grains?). At the opposite side of the surface, at the north-western section, I found the traces of a short wall, made from the same material, $0.55 \mathrm{~m}$ in width and $0.38 \mathrm{~m}$ in height. Obviously, the prehistoric constructions run outside the limits of the test-digging area. Comparing the bottom depths from S.1 and S.2, they are similar, as $-1.13 \mathrm{~m}$ in the first case, and -1.27 in the second, suggesting that those fittings were done more or less at the surface of the soil, with a superficial foundation, at the very beginning of the prehistoric settlement.

\section{THE POTTERY}

As the digging was short, the inventory is far from outstanding. I would stress, from the beginning, the missing artefacts, as would be the absence of the building nails, an astonishing fact for an archaeologist with eight campaigns in another Roman fort from Dacia Malvensis, as Răcari (Dolj County $)^{15}$. Metallic artefacts are very scars, as I found only half of an iron belt buckle. Another notable absence is made by tiles and bricks, except some splits about 1/10 from the original size, surely of secondary use.

The main corpus of inventory is made of pottery. Being this the first campaign on this site, a thorough examination seemed to me important. It have been collected 346 pottery sherds and classified 321. Nevertheless, the statistic is made up following the weight criterion:

TABLE 1: Classified pottery (weight from total)

\begin{tabular}{|l|l|}
\hline \multicolumn{1}{|c|}{ Category } & Share \\
\hline Prehistory from total & $39.49 \%$ \\
\hline Roman imports in all Roman Age pottery & $23.62 \%$ \\
\hline Roman type pottery in all local production & $38.33 \%$ \\
\hline Roman type pottery in all Roman Age pottery & $29.00 \%$ \\
\hline Chilia-Militari type in all Roman Age pottery & $45.29 \%$ \\
\hline Chilia-Militari type in all local production & $61.67 \%$ \\
\hline Medieval or modern & $00.41 \%$ \\
\hline
\end{tabular}

An important clue about the local pottery is the presence of relatively abundant mica flakes in the ceramic paste. This is simply excluding any sherd on which the mica is absent, from the list of the local products. Of course, this makes easier the identification of local fabric ${ }^{16}$, but do not solve the entire puzzle. For instance, there are amphorae having mica in composition, but those cannot be local products. One can easily guess that, similarly to amphorae, could be any other imported artefacts, but we cannot really discriminate them ${ }^{17}$. This type of ceramic paste is, more or less, specific for all the sites of Limes Transalutanus, south of the Argeș River; this is why the concept of "local manufacture" has a loose meaning, as "not brought from far".

I will discuss further mainly the Roman Age pottery. I used two separate sets of fabric classification. The first is generic, working with terms like "fine" and "coarse", "red" (oxidised

15 Teodor 2009; Teodor, Nicolae 2013.

${ }^{16}$ Not without risks, as much of the pottery made on Novae contain mica (sometimes abundant) in the paste (Tomas 2003, 121-126).

${ }^{17}$ Of course, a complex archaeometric examination of these classes, made on intuition, is mandatory for the near future. 
pottery) and "grey" (reducing firing). Such a classification is not only easier to follow, but it addresses a certain issue: what is the appearance of the artefact. Many products of the age use thin coats of finer clay (or slip), in order to improve the look of the surface. Certainly, current classifications cannot describe both the surface and the core of the pot, or they can, paying the price of intricate descriptions and minced statistics.

TABLE 2: Generic classes of fabrication (Roman Age)

\begin{tabular}{|l|l|}
\hline Generic class & Share $^{18}$ \\
\hline fine, red & $5.78 \%$ \\
\hline sandy but fine, red & $16.18 \%$ \\
\hline half fine, red & $16.76 \%$ \\
\hline half coarse, red & $9.25 \%$ \\
\hline fine, grey & $12.14 \%$ \\
\hline half fine, grey & $21.39 \%$ \\
\hline half coarse, grey & $16.18 \%$ \\
\hline coarse, grey & $0.58 \%$ \\
\hline kaolin & $1.73 \%$ \\
\hline
\end{tabular}

A second set of fabric's classification was made looking at the sherd's section and describing the elements visible with the naked eye, accounting only the composition of the paste, not the colour. It have resulted 31 types, but many of them are just variants of some main types, with variables given by the presence/absence of a certain element, or the variation over frequency. A detailed description of those 31 types would exceed a general report about the digging, postponing them for a study oriented on pottery. What I will do yet here is describing the frequency of the top 5 types, as being representative for Băneasa:

1. sandy but fine, grains up to $1 \mathrm{~mm}$, mica flakes discreet, hollows up to $1 \mathrm{~mm}$ (19 sherds grey, 12 sherds red, 3 imports);

2. fairly fine, sandy, silica up to $2 \mathrm{~mm}$, mica flakes, all abundant (20 sherds grey, 3 red, 1 import);

3. sandy but fine, lots of mica, especially on the faces, opaque minerals up to $1 \mathrm{~mm}$ (14 red, 3 grey, 1 import);

4. half coarse, silica up to $3 \mathrm{~mm}$, plenty of mica flakes (mainly on the faces), very fine (12 grey sherds, 2 red);

5. fairly fine paste, lots of mica, silica only accidentally ( 12 grey sheds, 6 red).

There are at least two outcomes for the most frequent paste types enumeration: first, that the general quality of the preparation is good, demi-coarse types being rare, and coarse types very rare; second is that the procedure followed - a bear-eye identification of the paste compounds, with the usual knowledge of an archaeologist - cannot separate pottery certainly made on place by that certainly imported. Both petrography and origin expertise based on the chemically composition are required for a definite classification.

Turning back to data contained in Table 2, most of the "red" items are imports or locally made "Roman" wares, and the "grey" items are mostly considered as Chilia-Militari pottery type.

Within the last, red kitchen ware occurs ${ }^{19}$, but there is no way to make a distinction between that and the "Roman" type (the reason of the brackets will become soon clear).

\footnotetext{
${ }^{18}$ This report is excluding the sherds secondary burned up to the point of making their original colour uncertain. This is why the sum of the "red" (or "grey") classes does not fit data from the Table 1.

19 Bichir 1984, 37-38. Note that about 35\% from the wheel made pottery is sandy and red, or what the author named "ceramică zgrunţuroasă de aspect provincial roman" (sandy ware, Roman provincial like). See also Teodor, Bădescu, Haită 2015, 96, Table 3.
} 
The grey ware, having its roots in La Tène Age, for wheel made pottery, is a common place for Dacians, Getae and later Carpi ${ }^{20}$.
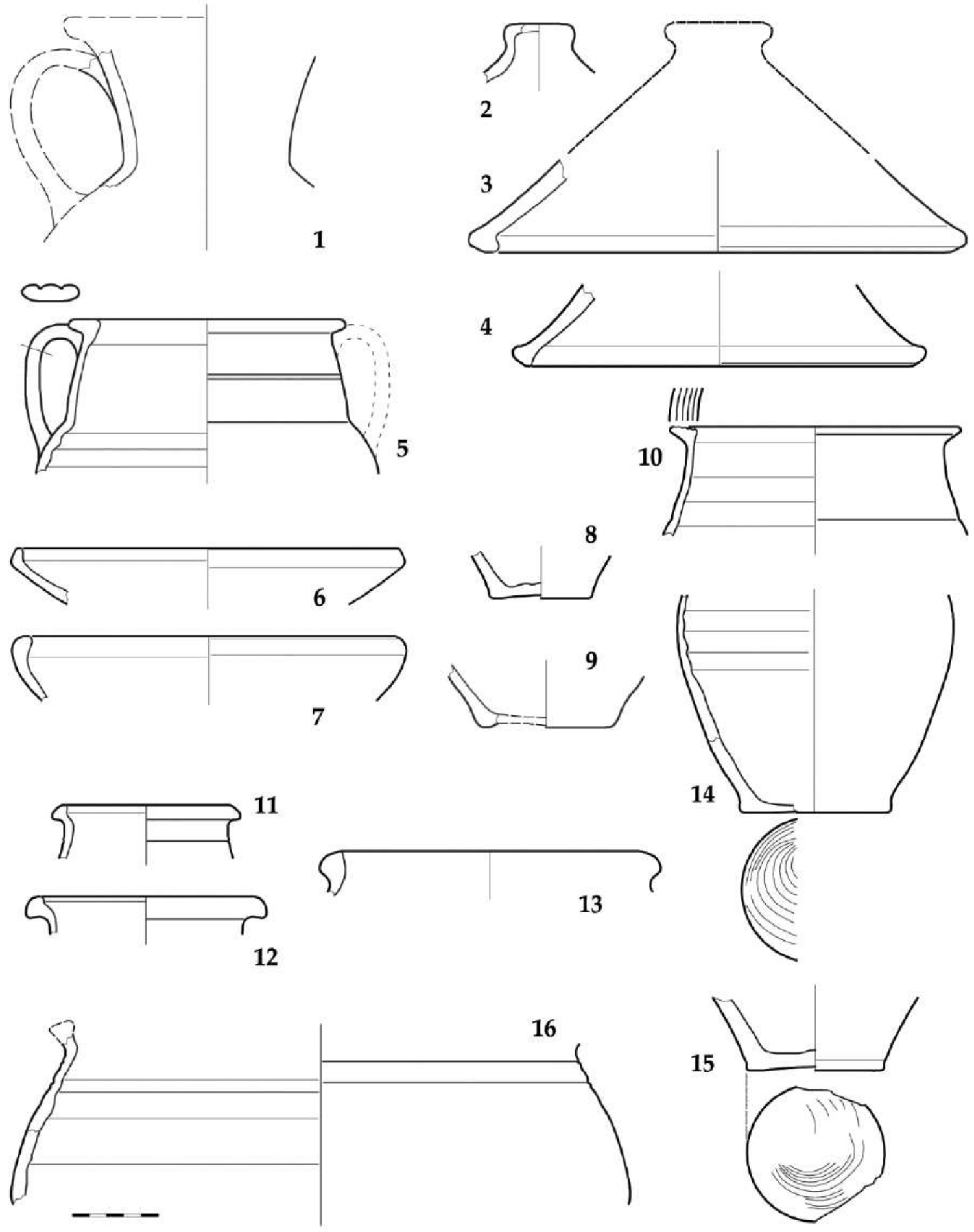

FIGURE 8: Grey ware (“Chilia-Militari”).

Jar (1), lids (2-4), two handle pot (5), bowls $(6,7$; 9?), pots $(8-15)$;

fine, sandy $(1,5,9,10)$, half fine $(2,6,7,11-13,15)$, relatively coarse $(3,4,14)$.

${ }^{20}$ We are speaking yet about different shades of grey. Within the La Tène tradition wheel made pottery is usually bright grey. Chilia-Military pottery is basically dark-grey, although lighter shades occur. One has to add that the grey pottery of Principate Age is common for every Roman province with a La Tène history (i.e. Celtic, or with Celtic influence, as in Dacia), as Gallia or Britannia (see, for instance, Davies, Tomber 1994, 74-119). 
Reviewing the data published by Gheorghe Popilian, I found out that grey flagons (or jugs) ${ }^{21}$ one can find in Oltenia, but fewer than $4 \%^{22}$. In order to have clear facts, lets say that fine grey ware is absent at Novae, before the late fourth century ${ }^{23}$, the closest great Roman site from the other bank of the Danube. We can already conclude that this kind of pottery, found not only in "classic" ChiliaMilitari settlements, but also inside the Roman forts, is a distinctive hallmark of the Roman culture east of Olt River. This is why I made the distinction between the conventional "Roman" red pottery, usual anywhere, and Chilia-Militari type, which is - in my advice - a local species of Roman pottery, or, simpler, a local type of Roman provincial pottery.

Yes. No doubt Roman culture! Although (dark) grey, Chilia-Militari shapes are of Roman type, a fact striking obvious on drawings (FIG. 8, especially no. 5, which is almost black!) ${ }^{24}$. Anyway, some facts could attract attention, as the dimension of the jar from the FIG. 8/1, having a neck diameter of $10 \mathrm{~cm}$, unusual in a fully Roman environment, but present in Chilia-Militari sites ${ }^{25}$. Another "too big" item is the lid from fig. $8 / 3$, with a rim diameter of $29 \mathrm{~cm}$, raising the question of the use: to cover kitchen pots, or storage pots? ${ }^{26}$ Large pots are rather sparse in Roman Oltenia ${ }^{27}$.

At least interesting is the triangular section rim from fig. 8/10, decorated with four grooves on the top of the flat rim. We can count in Oltenia a few rim triangular sections ${ }^{28}$, also some decorated flat rims ${ }^{29}$, but an exact analogy I was not able to find in southern Romania.

Also interesting but less documented fact is the pot with string marks on flat bottoms, as those in fig. 8/14, 15, resulted from detaching the pot from the wheel. This is a technological detail archaeologists do not pay attention, thus it seems special ${ }^{30}$.

The locally made Roman pottery is the lowest represented category, so far, at the large fort from Băneasa. At the FIG. 9 one can see fragments of two large jars (1-2) ${ }^{31}$, without a good matching in Roman Oltenia, three lid's buttons (4-6), a small cup (7), the rest being pots, of which only 9 and 12 are kitchenware. Number 10 is a refusal, a strip of clay connecting accidentally the shoulder and the external rim; the flaw was possible to be corrected, after burning, but probably the product has had

${ }^{21}$ We have a problem denominating some of the archaeological pottery shapes, and the flagon vs. jug is one of them. Preparing for a paper (Teodor, Bădescu, Haită 2015) I made a research about how British archaeologists use words to name shapes. This way I come to read a relatively new ceramic monograph in which a liquid recipient with a narrow neck is called "flagon" (Davies, Tomber 1994, e.g. 30-31 with fig. 22/52-59), a term used myself in the mentioned study. The same think is yet sometimes named a "jug", for instance in Opait 2004 (164-165, Plates 45-46), Tomas 2003 (including in the title), but the Internet provides lots of examples, as Ebay (http://www.ebay.co.uk/itm/Original-ancient-Roman-ceramic-vessel-artifact-Jug-Vase-pottery-Kylixguttus-2AD-/302193191077), Wikipedia (article using both, see https://en.wikipedia.org/wiki/Ancient_Roman_pottery), BBC (http://www.bbc.co.uk/ahistoryoftheworld/objects/MF3CNWBERti4tRwPGxeIYQ), and, no more, no less than British Museum, with a long list of artefacts from their public database; in one case, interestingly, there are used both names (jug and flagon) for a single artefact (no. 1982,0729.58). In order to avoid misunderstandings one should define the terms in each paper.

22 Teodor, Bădescu, Haită 2015, 106.

${ }^{23}$ Agnieszka Tomas - personal communication. See also Tomas 2003, esp. 132.

${ }^{24}$ Popilian 1976, two handles pots, type 3, cat. 399-404 (esp. 403). Note that all analogies from Oltenia are made of fine, oxidised paste, but our artefact is fine, but sandy and almost black.

${ }^{25}$ Teodor, Bădescu, Haită 2015, 107 with fig. 4; see also the concluding comments from the pages 127-128.

${ }^{26}$ The sherd has strongly secondary burn, preventing observations related to boiling traces. Note that the largest lid known from Oltenia (Popilian 1976, 220, cat. 936), has a diameter of $22 \mathrm{~cm}$, being... grey and found fort's horreum from Drobeta.

${ }^{27}$ Popilian 1976, plates XXXIII-XXXVI (cat. 315-369), while the storage pots are quite rare, only two in Popilian's illustration, see Plate LXI, no. 746-747, both of them having the rim diameter of $29 \mathrm{~cm}$, idem, page 208; in his general commentaries Popilian $(1976,114)$ have said that fragments of storage pots are encountered both in urban and rural environments, without giving a relative quantification.

${ }^{28}$ Popilian 1976, Plates XXXV/349, XXXVI/356.

${ }^{29}$ Popilian 1976, Plate XXXVI/358 (handless pot), XXXIX/395, 399, 400, 401, 404 (all pots with two handles, but all with other morphology).

${ }^{30}$ I've seen similar marks on third century pots from the fort Răcari (Dolj county), but that lot of artefacts it is not published. This detail can be seen on post-Roman pottery, as long as the fast wheel stayed in use (late sixth century, for instance Dolinescu-Ferche 1984, 133, fig. 9/5, 12).

${ }^{31}$ The problem is the size. I couldn't find anything similar in the control lot from Oltenia (Popilian 1976, pl. LX, no. 410416). All of them have neck diameter at most $10 \mathrm{~cm}$, which is small compared with the reconstructed shape from my, Fig. $9 / 1$ (which, in fact, could be taller, with a narrower neck). Another fact is the proportion between flagons (with narrow and long neck) and the jars (with larger, but shorter necks), in Oltenia the former being about ten times many than the last. The hazard of discovery brought at Băneasa, so far, four fragmentary jars but no flagons. 
other problems and it was rebutted. The shape of the rim does not fit the needs for cooking, nor for pouring, thus maybe it was intended for storing (although the rim diameter is only $12 \mathrm{~cm}$ ). Considering the flat rim decorated with parallel grooves, it worth mention that in Oltenia such an issue encounter mainly on two handles pots ${ }^{32}$, handles which I could not see on a presence of only $18 \%$ from the circumference.
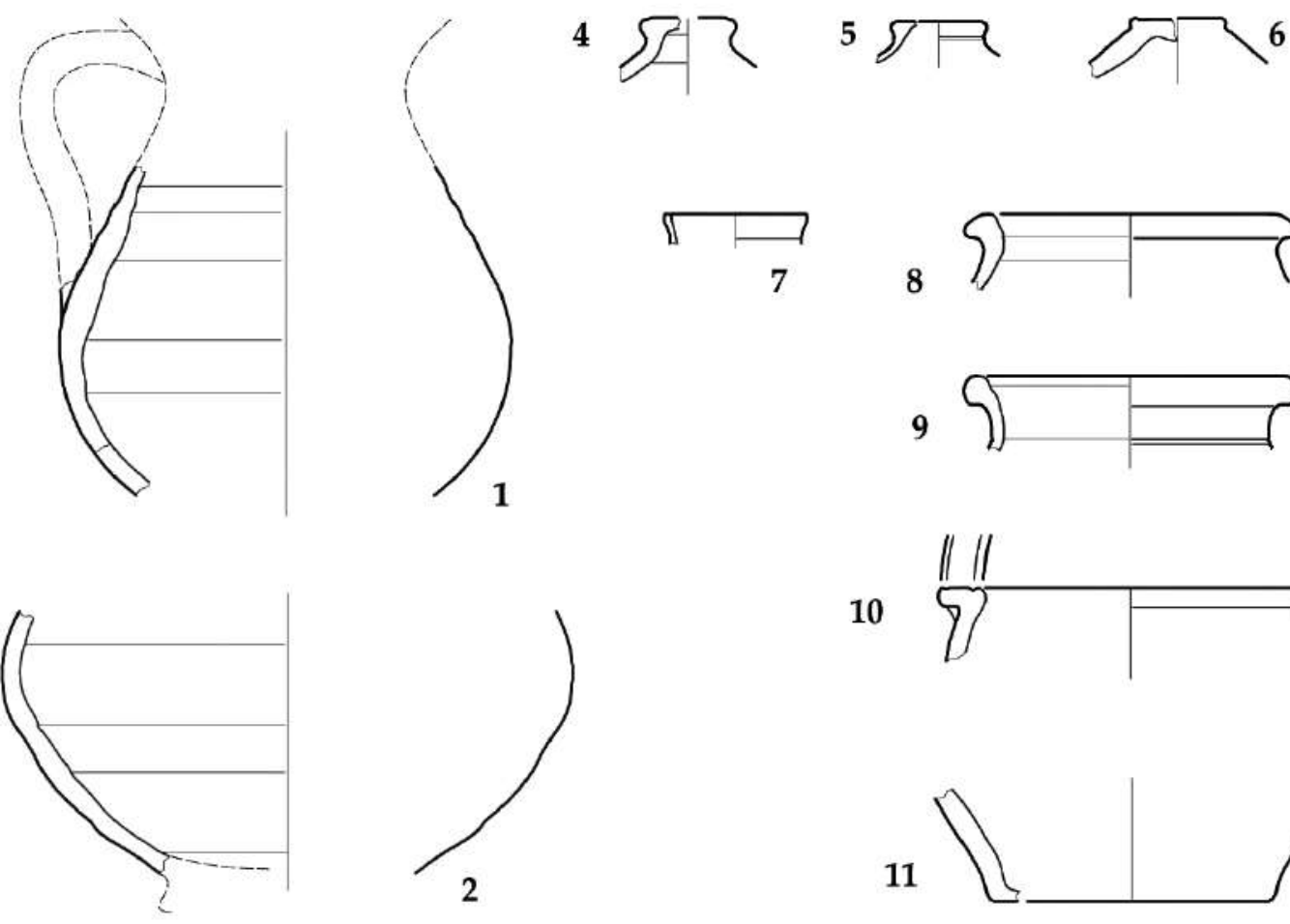

10
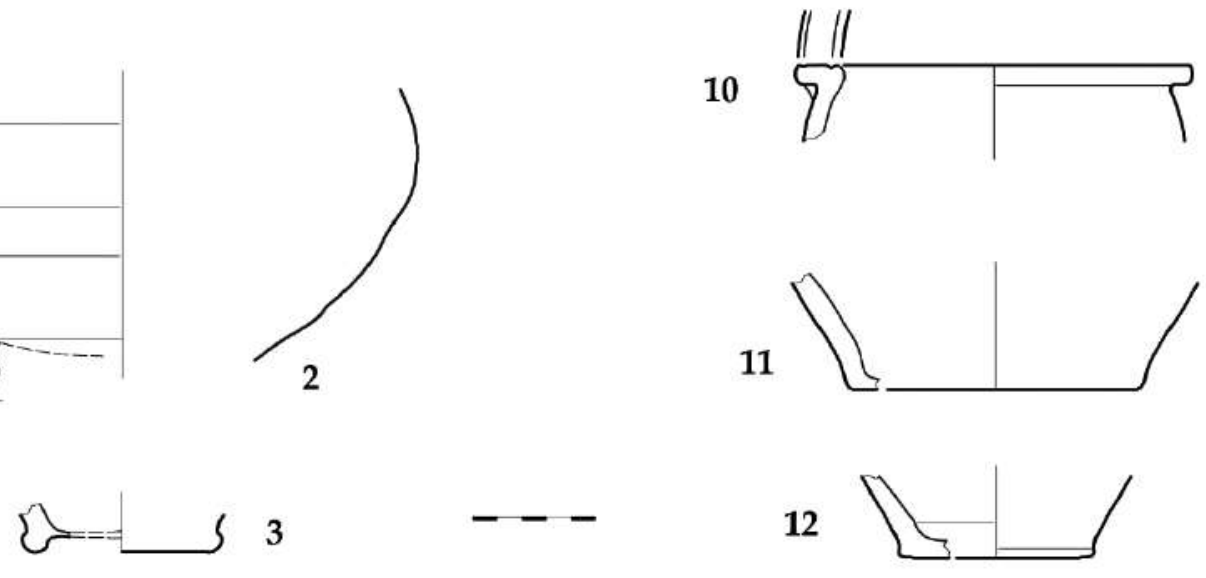

3

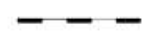

12
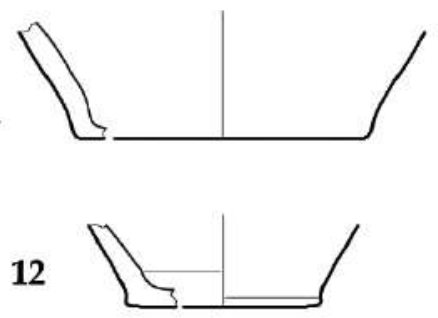

FIGURE 9: Locally made Roman pottery.

Jars $(1,2 ; 3$ ?), lids (4-6), cup (7), pots $(8,9,11,12)$,

two handles pot (?), refusal (10);

fine (possibly import, 3$)$, fine, sandy $(1,2,4,5,10)$,

half fine $(6-8,11)$, relatively coarse $(9,12)$.

Many of the sherds considered as imports are parts of amphorae (FIG. 10/1-7). They are very fragmented and difficult to be ascribed to certain classes, but my best guesses are as follows: Pontic type 4 Paraschiv for fig. 10/133; second type from Oltenia for fig. 10/2 34 ; Pontic Type 3A Paraschiv for the long and straight handles from the fig. $10 / 3$ and $4^{35}$; Pontic Type 3B Paraschiv for the fig. 10/5, falling

${ }^{32}$ Popilian 1976, Plate XXXIX, no. 395, 396, 399, 401, 404.

${ }_{33}$ Paraschiv 2006, Plate 3, no. 22, see also page 45, cat. 22, discovery in Tomis, dated for the second and third century, having the same shade of colour but coarser than the item from Băneasa.

${ }^{34}$ Popilian 1976, 171: brick red paste, yellowish slip, found in Grojdibod, which is strictly correct for Băneasa item, which has well preserved slip, but only outside, see Plate XV/195, where the item is classified in the second type.

${ }_{35}$ Paraschiv 2006, Plates 1/7, 2/8, 9-11, see commentaries (pages 19-21) and the catalogue (page 43). The type is very frequent in Moesia Inferior, but very early (first to second century AD), which does not fit the presumptive chronology for the large fort from Băneasa. It could be yet the variant B of the same type, which has "the same shape, but the body is shorter and larger" (Paraschiv 2006, 21), although the published drawings (Paraschiv 2006, cat. 12-17, plates 2-3) do not fit the shape of the handles as well variant B is dated for the second and third centuries, having a good frequency in Novae. 
thus in the same category with the previous two, with the mention it was not found in the same place; the next two, being just small parts from the neck and rim (FIG. 10/6-7), are difficult to be classified, nevertheless, amphorae shrinking towards the rim are not many, thus I would try Kapitän $2^{36}$.

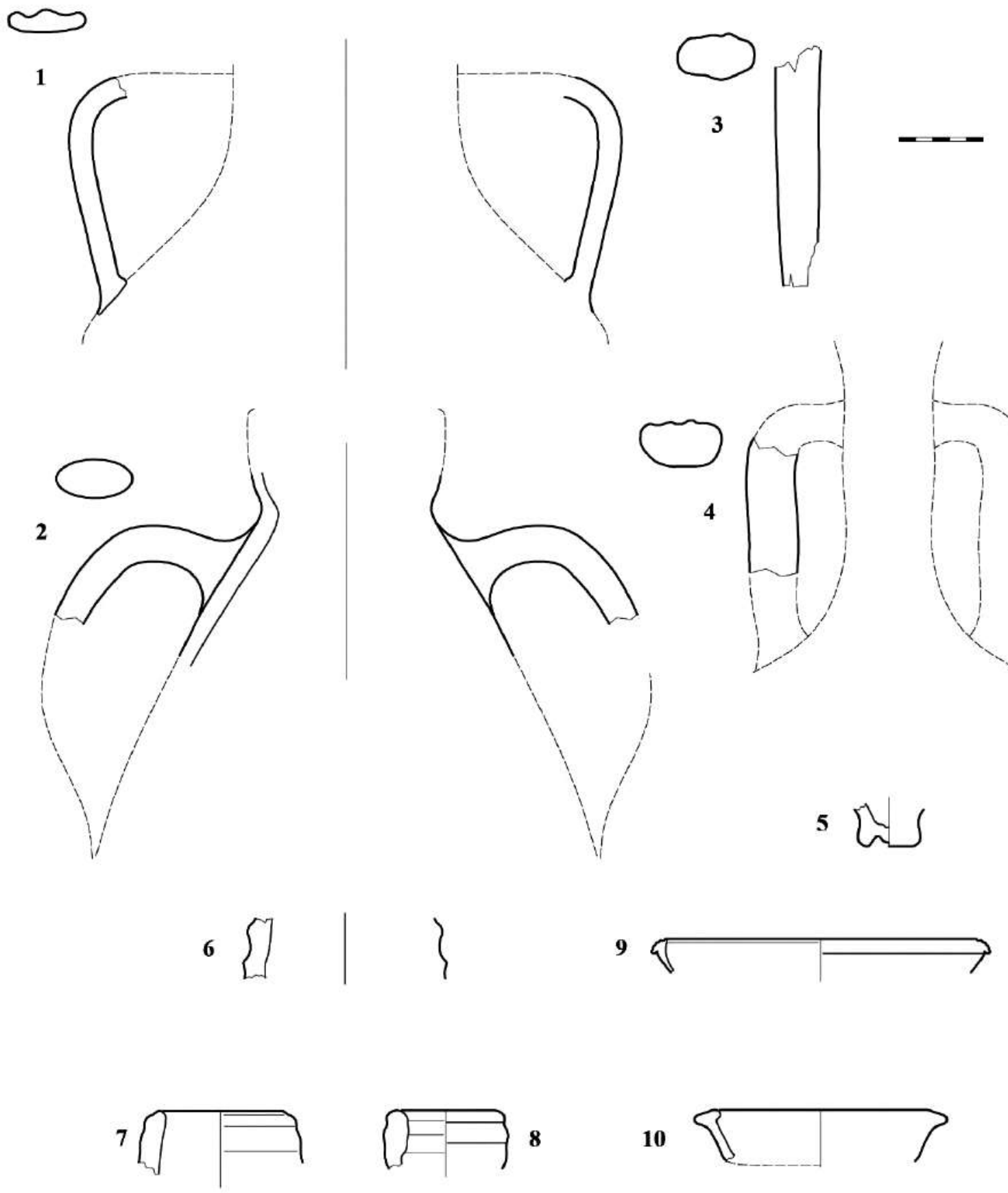

FIGURE 10: Roman imports. Amphorae (1-7), flagon (8), bowl (9), plate (10); yellowish-red (1, 7), brick-red (24,6 ), pale yellow (5), whitish-grey (8), dark red (9), whitish (10); fine paste $(2,7,9)$, fine but sandy $(1,5,10)$, mostly fine $(3,4,8)$, half coarse (6).

Our artefacts (seemingly a pair from the same object) could also fall in the type Kapitän 2 (http://archaeologydataservice.ac.uk/archives/view/amphora_ahrb_2005/), probably of eastern Mediterranean origin.

36 Amphora Project (http://archaeologydataservice.ac.uk/archives/view/amphora_ahrb_2005). Interesting to note, Kapitän 2 has long, straight handles, like those in Fig. 10/3, 4, and hollow base, as 10/5), the typical dimension for the rim's diameter $(7 \mathrm{~cm})$ being met, although they certainly do not belong from the same object, having different fabrics. 
The interesting thing about the sherds from amphorae is that all except one (FIG. 10/5) were found in the same place, in Surface E, immediately west of the barrack, in the ploughed layer or close. This is weird, because we should imagine a small deposit of edibles in the side of the barrack, which is unlikely (being an insecure place); more probably, the storage containers were kept in the barrack, at some height above the floor. We remember that the wall of the barrack has crumbled westward, dragging out all its content. Unfortunately, that area is strongly affected by the agricultural works and erosion, the artefacts being repeatedly broken and rolled downhill. From the same location were also recovered the fragments of a flagon and a bowl. The only piece found on the barrack's floor (from the drawn objects) is the dish, made of a whitish paste, containing kaolin, but not very clean or bright. This object comes, very likely, from an area of southern Dobruja (Rom. Dobrogea), where kaolin based clays are available ${ }^{37}$.

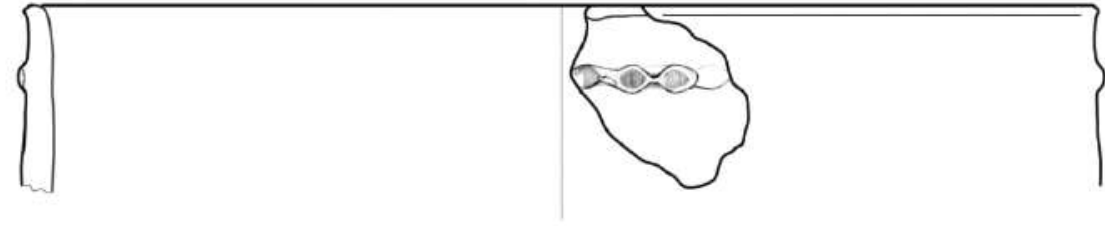

2
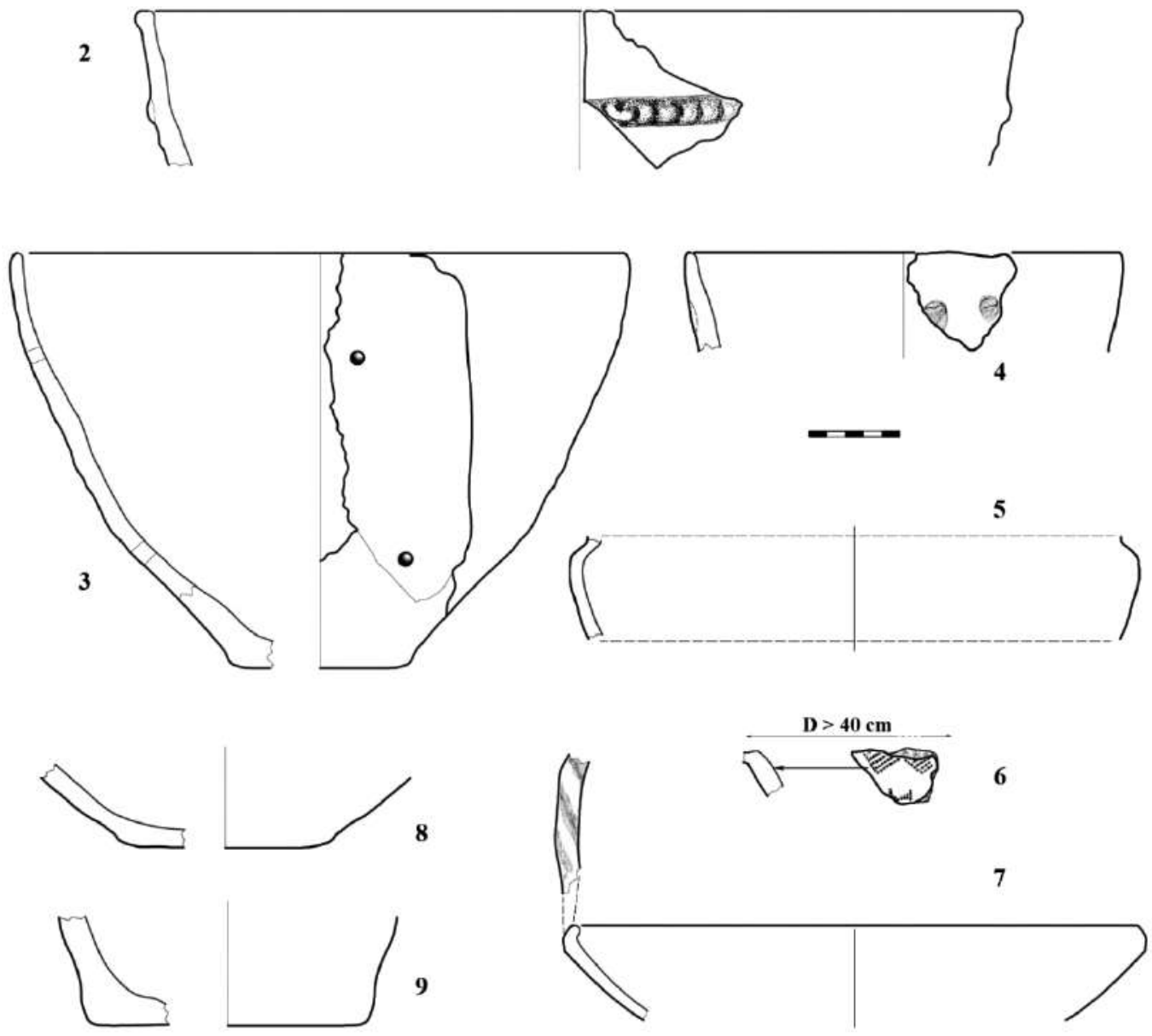

9

FIGURE 11: Prehistoric pottery. Very large open forms $(1,2)$, large open forms $(3,4)$, large pot $(5)$, large bowls $(6,7)$, bottoms $(8,9)$; mostly fine $(3,6,7)$; half coarse $(1,2,4,5,8)$, coarse $(9)$; reddish yellow $(1,5)$, yellowish (2-4), brick red (6), yellowish grey (7), grey (8).

\footnotetext{
${ }^{37}$ Personal communication Dr. Valentina Cetean, researcher at the National Geological Institute. There are also several kaolin made dishes known from Oltenia, classified by G. Popilian within the types 3 (made exclusively from this kind of paste!) and 5, but there is no morphological match (Popilian 1976, 214, cat. 843-847 and 857, with plates LXIX and LXX).
} 
About the Prehistoric pottery I will restrain myself to some descriptive facts, not being trained in the matter. The ceramic paste contains almost always crushed sherds, visible with the naked eye, most likely herbs, and, surprisingly, very few mica flakes ${ }^{38}$. The burning is oxidized, of good quality, although incomplete (with darker, greyish core), the pottery being consistent and very hard. The modelling is right, but not very carefully. All the measured sherds bespeak about generally great dimensions. The most recurrent shape is an open recipient, large or very large. The last category has a strip of clay bonded horizontally in the upper part, decorated with fingerprints, having diameters around $50 \mathrm{~cm}$; the former could be decorated with fingerprints in the same area, but directly on the body. I was able to reconstruct, from disparate fragments, only one shape (FIG. 11/3), which have some holes through the body, but the reason is not obvious at all; it has only one hole in its upper third (being preserved only less than one fifth from the circumference of the rim), but two on all the lower body (for which it is preserved most of the circumference) ${ }^{39}$. Only one pot - also large - has a constitution of a "closed" morphology (FIG. 11/5). Another type of decoration is made by straight prints made on the rim, diagonally (FIG. 11/7), with a large, round section object. Probably the most expressive decoration occurs on the object depicted at the FIG. 11/6, with a geometric decoration made from small punches, with a square like tip. Unfortunately, the fragment is small, although it comes from a very large recipient as well.

Although not properly "pottery", I have to mention here that were found fragments of a large tray, made of well burned clay, consistent, of the same composition as the coarse pottery, including vegetal remains and crushed sherds. The tray was thick (around $5 \mathrm{~cm}$ ), with the edge bent upwards at $40^{\circ}$. Though no obvious traces of secondary burning were found, its use could be as a portable device above a hearth, in order to dry seeds ${ }^{40}$.

Relaying on two pot sherds (Fig. 11/6-7) I would preliminary date the prehistoric site in the early stages of the Iron Age. Future diggings surely will provide more specific data. It is to add immediately that in the area from the southern part of Teleorman County there are plenty of large mounds, most of them ploughed. Future diggings surely will provide more specific data. Speaking of Prehistory, it is to add immediately that in the area from the southern part of Teleorman County there are plenty of large mounds, most of them ploughed. Two of them are quite close to the digging place. Only $180 \mathrm{~m}$ north-northeast of the large fort lays a "small" mound, heaving $32 \mathrm{~m}$ in diameter and 1.8 $\mathrm{m}$ preserved in height (although ploughed). A second tumulus, much larger, is located $600 \mathrm{~m}$ northeast from the fort, near the intersection of the National Road with a local road heading the village Băneasa; this one, although chopped several times, on at least two sides, still has a diameter of $67 \mathrm{~m}$, and a height of $6 \mathrm{~m}$. This mound, located only about $40 \mathrm{~m}$ behind the embankment named "Troian" - a former palisade marking the limit of the Empire - is suspected of being used by Romans as an observation post (if not a proper turret) ${ }^{41}$. None of them are recorded in the national database for archaeological sites ${ }^{42}$.

\section{SOME CONCLUDING REMARKS}

The test digging at the south-western corner of the large fort from Băneasa has confirmed the erosion disturbing effects. The embankment of the palisade - agger - still higher than one meter in the late $19^{\text {th }}$ century is now completely flat, following the general tilt of the field $\left(2^{\circ}\right)$ towards southwest. Only the deepest pole of the palisade structure could be found, completely burned, to the bottom. Fortunately, the inner part of the fort, including the marginal barrack from the area, are much better preserved, showing a two layer evolution (one before the great fire, one after). Surprisingly, on

\footnotetext{
${ }^{38}$ They can be seen in almost each case. Nevertheless, the Prehistoric ceramic paste has in average less mica than the "local" Roman Age pottery. I do not have a good explanation for that.

${ }^{39}$ I cannot exclude the so called "reparation holes", but no convincing proof is available, not having a pair of holes.

${ }^{40}$ Fragments were discarded in the so called "one meter trench", thus their original stratigraphy is not known. Looking at the composition of the clay, it is probably prehistoric.

${ }^{41}$ Teodor 2016b, 80-83, figs. 16-19.

${ }^{42}$ Repertoriul Arheologic Național, at http://ran.cimec.ro/
} 
the same spot was discovered also a prehistoric settlement, developing an anthropic layer of over half a meter.

The barrack had at least two sub phases, revealed by traces of levelling and sheets of clay. The barrack burned up also, but far from the intensity of the palisade, although the distance is small (around $4 \mathrm{~m}$ ). The burned layer of the barrack is made up from lots of small pieces of coal (burned thin woods) and ashes from a vegetal roof. All posts and the heavy structure of the roof have been recovered and reused. In the coming period the place has been converted in an industrial area, of military use, as pottery production or scrap metal melting.

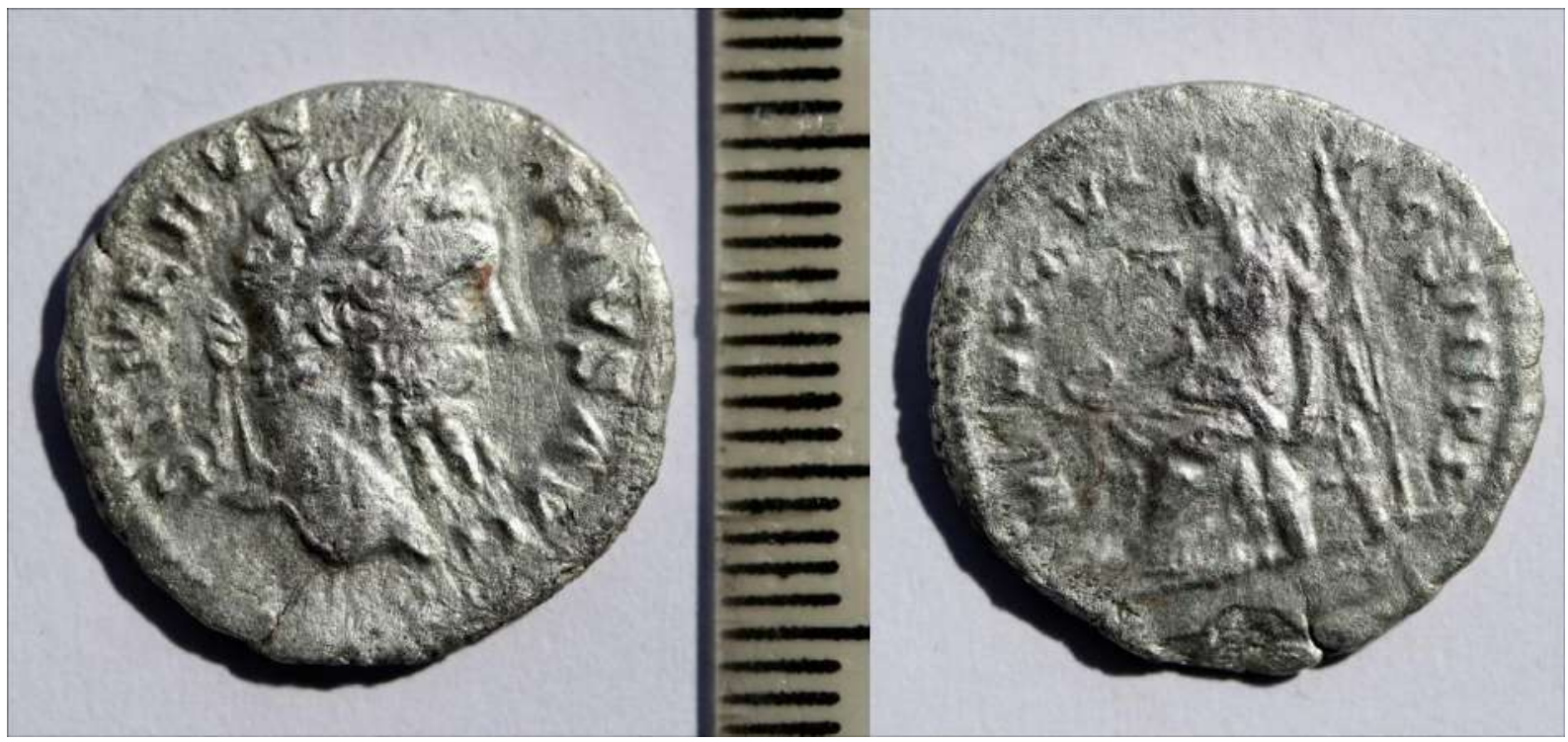

FIGURE 12: Denarius minted by Septimius Severus in 208 (TR P XVI).

The chronology is suggested by a unique artefact, but excellent located: a denarius on the barrack's floor, issued by Septimius Severus in 208 (FIG. 12) ${ }^{43}$. The coin is circulated for a while, but it is in a good shape, my estimation being that it was used for a span of time between 10 and 20 years. More or less, it was lost around the year 223, probably when the fire raged.

The Roman Age pottery is relatively well balanced in three classes: the grey ware of the so called Chilia-Militari culture (yet prevalent), the reddish, locally made Roman ware ${ }^{44}$, and imports, mainly connected with food logistics. The ratio recorded in this small digging (45.29\% for ChiliaMilitari type, see Table 1) is not necessarily relevant; on the contrary, a systematic field survey on a wider area $(260 \times 40 \mathrm{~m})$, from the western side of the fort, delivered different figures, Chilia-Militari pottery dropping down to $32.3 \%$. This is still very much, considering that no archaeologist working on Limes Transalutanus ever mentioned $\mathrm{it}^{45}$. The situation is pretty much the same for all investigated sites of this Roman frontier, south of the Argeș River, with statistics indicating a strong presence of the local population (or, at least, potters...), between one third and one fourth ${ }^{46}$.

The extension of the prehistoric settlement will be tested by the future diggings. The systematic survey showed (a small amount) of such pottery all over the western part of the large fort, as well as a flint split. In the test digging the anthropic layer is substantial (up to $0.6 \mathrm{~m}$ ) and not due to erosion and rolled over artefacts. In the northern corner of the Surface 1 were discovered five large sherds from the pot drawn at the FIG. 11/3, laying horizontally at the depth of $0.85 \mathrm{~m}$, thus on a certain

${ }^{43}$ Cleaned and determined by Dr. Mihai Dima, for which I am grateful. See also a catalogue for Severus Alexander: http://www.wildwinds.com/coins/ric/septimius_severus/i.html.

${ }^{44}$ We do not have a straightforward method to accurate make the difference between Chilia-Militari and "Roman" local pottery production, as no comparative study has been done so far. For more detailed commentaries of this issue see Teodor, Bădescu, Ştefan 2017, last four paragraphs.

45 Maybe with exceptions noted hastily, as Cantacuzino $(1945,456)$ did, mentioning a grey bowl found in a layer with ashes (in trench B, made at the northern curtain), probably a barrack.

${ }^{46}$ See Teodor 2016c, section 4; Teodor, Bădescu, Ştefan 2017. 
foot level, which is in the upper part of the prehistoric level. I am supposing now that the settlement is restricted for areas close to the edge of the terrace, due the proximity of the fresh water, at least three springs being today active at the half way between the terrace and the meadow, in a range around 50 $\mathrm{m}$ from the fort precinct. This is another good reason for Romans to do a fort in this location, despite the relatively poor visibility eastward. ${ }^{47}$

There is a tricky issue I am not able to explain today: the middle embankment and the second phase of the fortress. As I said before, that embankment is not burned, which means that the great fire was put to the palisade (mainly) at the end of the first phase, and not in 245-47. Future diggings, at the eastern precinct, might explain exactly how the precinct was remade. The outcome is that one might expect also two phases of construction for the long embankment of the frontier, as long time ago stated ${ }^{48}$. The two mechanical diggings made so far (also in 2016) did not provide yet any clue of that kind $^{49}$.

The small fort from Băneasa, located $226 \mathrm{~m}$ northeast from the large fort ${ }^{50}$, stretching $60 \times 48$ $\mathrm{m}$ (between battlements) ${ }^{51}$, oriented north-south, does not have advanced research so far. The only useful observations, so far, would be that it was not burned, and that the density of artefacts on its surface is far lower (several times!) than on the large fort. My best guess, at this stage, is that the forts were not strictly coeval, the smaller could be probably dated in the early second century. Giving a clear answer in the matter is important, clarifying the route of the Roman army in the Dacian Wars.

\section{BIBLIOGRAPHY}

Bichir 1984

Bogdan-Cătăniciu 1977

Bogdan-Cătăniciu 1997

Cantacuzino 1945

Davies, Tomber 1994

Dolinescu-Ferche 1984

Opaiț 2004

Paraschiv 2006

Petolescu 2010

Popilian 1976

Teodor 2009

Teodor 2015
Gh. Bichir, Geto-dacii din Muntenia în epoca romană, București, 1984

Ioana Bogdan-Cătăniciu, Nouvelles recherches sur le limes du sud-est de la Dacie, in J. Fitz (ed.), Limes: Akten des XI. Internationalen Limeskongresses (Székesfehérvár, 30.8.-6.9.1976), Budapest, 1977

Ioana Bogdan-Cătăniciu, Muntenia în sistemul defensiv roman (sec. I-III p. Chr.), Alexandria, 1997

Gh. Cantacuzino, Le grand cap romain situé de la commune Băneasa (dép. de Teleorman), Dacia, IX-X, 1941-1944 (1945), p. 441-472

B. Davies, R.S. Tomber, A dated corpus of early Roman pottery from the City of London, Museum of London \& Council for British Arhcaeology, 1994

Suzana Dolinescu-Ferche, La culture Ipotești-Cândești. La situation en Valachie $\left(\mathrm{V}^{\mathrm{e}}-\mathrm{VII}^{\mathrm{e}}\right)$, Dacia, N.S., 28, 1984, p. 111-147

A. Opait, Local and imported ceramics in the Roman province of Scythia ( $4^{\text {th }}-6^{\text {th }}$ centuries AD): aspects of economic life in privonce of Scythia, Oxford: Archaeopress, 2004

D. Paraschiv, Amfore romane și romano-bizantine în zona Dunării de Jos (sec. I-VII p. Chr.), Iași, 2006

C. C. Petolescu, Dacia. Un mileniu de istorie, Bucureşti, 2010

Gh. Popilian, Ceramica romană din Oltenia, Craiova, 1976

E. S. Teodor, Roman fort from Răcari (Dolj County, Romania) and its four stages. Plannimetry, stratigraphy and chronology, in Field researches 20032006, Proceedings of the $20^{\text {th }}$ Congress of the Roman Frontiers, 4-11 Sept. 2006, Léon, Spain, 2009, vol. 2, p. 1524-1539

E. S. Teodor, The Invisible Giant: Limes Transalutanus. An Overview south of Argeş River, Târgovişte, 2015

\footnotetext{
${ }^{47}$ Similar situations can be acknowledged for the forts located in Putineiu or Urlueni. They were close to a major stream of the area (Călmății for Putineiu and Cotmeana for Urlueni), which is good for herds, but people and horses need fresh water.

48 Bogdan-Cătăniciu 1977, 338-344; Bogdan-Cătăniciu 1997, 88-89.

${ }^{49}$ Teodor (forthcoming).

${ }^{50}$ And 124 m afar the national route Turnu Măgurele - Roșiorii de Vede.

${ }^{51}$ Estimation following data provided by the terrain model obtained from the drone, thanks to my mates from the research project.
} 
Teodor 2016a

Teodor 2016b

Teodor 2016c

Teodor (forthcoming)

Teodor, Nicolae 2013

Teodor, Bădescu, Haită 2015

Teodor, Bădescu, Ştefan 2017

Tocilescu 1900

Tomas 2003
E. S. Teodor, Studiul identificării așezărilor civile pe frontiera transalutană, in E.S. Teodor (ed.), Arheologia peisajului și frontierele romane, Târgoviște, 2016, p. 97-122

E. S. Teodor, De pază pe Limes Transalutanus. Despre turnurile de pe segmentul sudic, in E.S. Teodor (ed.), Arheologia peisajului și frontierele romane, Târgoviște, 2016, p. 67-96

E. S. Teodor, Tehnologia de cercetare a obiectivelor liniare (Interim report of the research project for 2016), http://www.limestransalutanus.ro/rapoarte/raport_etapa3.html

E. S. Teodor, Raport de diagnostic arheologic pentru județul Teleorman, CCA 2017 (secțiunea de diagnostic)

E. S. Teodor, Corina Nicolae, Civilians in the Fort. Răcari Case, Acta Musei Napocensis, 2013, 50/I, p. 157-180

E.S. Teodor, A. Bădescu, C. Haită, One Hundred Sherds. Chilia-Militari Culture Reloaded. Alexandria Pottery Case, Journal of Ancient History and Archaeology, 2 (4), 2015, p. 90-135

E.S. Teodor, A. Bădescu, D. Ştefan, Systematic field survey on Limes Transalutanus. Săpata Case, Journal of Ancient History and Archaeology, 4, 2 (forthcoming)

Grigore G. Tocilescu, Fouilles et recherches archéologiques en Roumanie. Communications faites à l'Académie des Inscriptions et Belles-Lettres de Paris, 1892-1899, Bucarest: Imprimerie du Corps Didactique, 1900

Agnieszka Tomas, Jugs from Novae. A Study on finds from 1960-99, Novensia, 14, 2003, p. 119-184

\section{LISTA ILUSTRAȚIEI}

FIGURA 1: Băneasa. Realitate virtuală de mare rezoluție $(0,1 \mathrm{~m}$ pentru ortofotografie și $0,2 \mathrm{~m}$ pentru modelul teren). Vedere de la sud-vest.

FIGURA 2: Castrul mare de la Băneasa, vedere model teren suprapus de magnetometrie.

FIGURA 3: Secțiuni topografice pe model teren de mare rezoluție suprapus de rezultatele magnetometriei, comparație a stării de conservare a colțurilor de nord-est și sud-vest.

FIGURA 4: Castrul mare de la Băneasa, planul săpăturii-test din septembrie 2016.

FIGURA 5: Stratigrafia comparată a săpăturilor din 1943 și 2016, la colțul de sud-vest al castrului.

FIGURA 6: Profilul secțiunii E, malul de sud-vest. Groapa arsă a palisadei.

FIGURA 7: Secțiunea 2, profil stratigrafic complet, în zona barăcii romane.

FIGURA 8: Ceramică cenușie („Chilia-Militari”). Cană (1), capace (2-4), oală cu două anse (5), castroane $(6,7$; 9?), oale (8-15); fabricaţie fină, nisipoasă $(1,5,9,10)$, semi-fină $(2,6,7,11-13,15)$, relative grosiară $(3,4,14)$. FIGURA 9: Ceramică romană produsă local. Căni $(1,2,3$ ?), capace $(4-6)$, cupe $(7)$, oale $(8,9,11,12)$, oală cu două toarte (?), rebut (10); pasta fină (posibil import, 3), fină, nisipoasă $(1,2,4,5,10)$, semi-fină $(6-8,11)$, relativ grosieră $(9,12)$.

FIGURA 10: Importuri romane. Amfore (1-7), urcior (8), castron (9), platou (10); roșu-gălbui (1, 7), roşucărămiziu $(2-4,6)$, galben pal (5), gri-albicios (8), roşu închis $(9)$, albicios $(10)$; pasta fină $(2,7,9)$, fină dar nisipoasă $(1,5,10)$, relativ fină $(3,4,8)$, relative grosieră $(6)$.

FIGURA 11: Ceramică preistorică. Forme deschise, de foarte mari dimensiuni $(1,2)$, forme deschise, de mari dimensiuni $(3,4)$, vas bitronconic mare $(5)$, castroane mari $(6,7)$, baze de vas $(8,9)$; fabricație relativ fină $(3,6$, 7); semi-grosieră $(1,2,4,5,8)$, grosieră $(9)$; gălbui-roșiatic $(1,5)$, gălbui $(2-4)$, roșu-cărămiziu (6), cenușiugălbui (7), cenușiu (8).

FIGURA 12: Denar emis de Septimius Severus în anul 208 (TR P XVI).

EUGEN S. TEODOR

Muzeul Naţional de Istorie a României, esteo60@yahoo.co.uk 